\title{
Effect of Cu and Zn on Maize (Zea mays L.) Yield and Nutrient Uptake in Coastal Plain Sand Derived Soils of Southeastern Nigeria
}

\author{
Ernest Ukpabi Eteng1, Demian Okwudiri Asawalam1, Anthony Osinachi Ano² \\ ${ }^{1}$ Department of Soil Science and Meteorology, Michael Okpara University of Agriculture, Umudike, Nigeria \\ ${ }^{2}$ National Root Crop Research Institute (NRCRI), Umudike, Nigeria \\ Email: eteng em@yahoo.com
}

Received 11 May 2014; revised 20 June 2014; accepted 1 July 2014

Copyright (C) 2014 by authors and Scientific Research Publishing Inc.

This work is licensed under the Creative Commons Attribution International License (CC BY).

http://creativecommons.org/licenses/by/4.0/

(c) (i) Open Access

\begin{abstract}
Laboratory, greenhouse and field studies were undertaken to investigate the status of $\mathrm{Cu}$ and $\mathrm{Zn}$ and to find out whether the addition of these nutrient elements in soils would increase maize grains and yield components and also, remediate their constraints in coastal plain sand derived soil of southeastern Nigeria, for optimization of maize (Zea mays L.) yields. Dry matter yields, plant concentrations, plant uptake, and maize grain yields were used to evaluate the effects of $\mathrm{Cu}$ and $\mathrm{Zn}$ levels. In both the greenhouse and field experiments, hydrated $\mathrm{Cu}$ and $\mathrm{Zn}$ sulphate fertilizers were applied to the soils in separate experiments at seven levels $\left(0,2,4,6,8,10\right.$ and $\left.12 \mathrm{~kg} \cdot \mathrm{ha}^{-1}\right)$ for $\mathrm{Cu}$ and $\mathrm{Zn}$ respectively. The recommended $\mathrm{N}, \mathrm{P}$, and $\mathrm{K}$ at rates of $120,60,30 \mathrm{~kg} \cdot \mathrm{ha}^{-1}$, respectively, were also used as basal application. The results showed the status of available $\mathrm{Cu}$ and $\mathrm{Zn}$ by $0.1 \mathrm{~N}$ $\mathrm{HCl}$ was found to be low in the soil. The application of $\mathrm{Cu}$ and $\mathrm{Zn}$ into the soils significantly $(\mathrm{P}<$ 0.05) increased maize dry matter production, concentration, uptake and grain yields. The estimated optimum rates for $\mathrm{Cu}$ and $\mathrm{Zn}$ under greenhouse environments were established at 10 $\mathrm{kg} \cdot \mathrm{Cu} \cdot \mathrm{ha}^{-1}$ and $8 \mathrm{~kg} \cdot \mathrm{Zn} \cdot \mathrm{ha}^{-1}$, respectively. Maximum uptake and grain yields in maize were also established at $10 \mathrm{~kg} \cdot \mathrm{Cu} \cdot \mathrm{ha}^{-1}$ and $8 \mathrm{~kg} \cdot \mathrm{Zn} \cdot \mathrm{ha}^{-1}$, respectively. However, maize response curve showed that for optimum grain yield, concentration for $\mathrm{Cu}$ was determined to be $10 \mathrm{mg} \cdot \mathrm{kg}^{-1}$, while for $\mathrm{Zn}$ it was $8 \mathrm{mg} \cdot \mathrm{kg}^{-1}$. The current study showed that though the soils have a severe $\mathrm{Cu}$ and $\mathrm{Zn}$ deficiency, which could be due to their strong sorption capacity and nutrients mining due to intensive and continuous cropping, maize production can still be increased considerably in this soil and other similar soils in the same agro-ecological zone within a coastal plain sand derived soil by applying $\mathrm{Cu}$ and $\mathrm{Zn}$ at rates of $10 \mathrm{~kg} \cdot \mathrm{Cu} \cdot \mathrm{ha}^{-1}$ and $8 \mathrm{~kg} \cdot \mathrm{Zn} \cdot \mathrm{ha}^{-1}$, respectively.
\end{abstract}

\section{Keywords}

Cu, Zn, Maize, Yield, Nutrient Uptake, Coastal Plain Sand and Acid Sands 


\section{Introduction}

Maize (Zea mays L.) is one of the most important high value cereals crops in many households in Nigeria [1] [2]. The crop is widely cultivated in soils of Nigeria, including the coastal plain sands, parent material of soils of southeastern Nigeria [3] [4], which is highly weathered, predominantly lateritic with frequently low in exchangeable bases and cation exchange capacity [5]. The soils are low in organic matter content and mostly acidic in reaction [6], and leaching due to high rainfalls regimes couple with low activity characteristics of the clay fraction and in fact sandy nature of the soils [4], and almost deficient/low in major and minor nutrient elements specifically $\mathrm{Cu}$ and $\mathrm{Zn} \mathrm{[7]} \mathrm{[8],} \mathrm{and} \mathrm{the} \mathrm{availability} \mathrm{of} \mathrm{these} \mathrm{nutrient} \mathrm{elements} \mathrm{to} \mathrm{maize} \mathrm{crop} \mathrm{is} \mathrm{conditioned} \mathrm{by} \mathrm{these}$ characteristics of the soil under review. Generally, micronutrient-deficient soils do not support optimum crop yields because plant growth becomes retarded by the deficiency, leading to low yields [4] [8] [9].

The application of $\mathrm{Cu}$ and $\mathrm{Zn}$ fertilizers to maize crop not only enhances its production, but also increases tissue content and cures these nutrient deficiency problems in human beings. With intensive and continuous cropping, arable soils have been depleted in the essential micronutrient elements especially, $\mathrm{Cu}$ and $\mathrm{Zn}$ and nutrient availability is further aggravated in acid sands of Southeastern Nigeria.

The approaches that have been used to replenish these micronutrients in southeastern Nigeria soils include crop rotation, manure application, and the use of crop residues; however, such methods and materials do not optimize crop yields due to the insufficient micronutrients supplied by these materials. However, soluble sulphate of copper and zinc fertilizers are some other sources of micronutrients that can be used to replenish these micronutrients in the soils but, due to lack of information and high prices of these nutrients and of course, low agricultural-based incomes, only a few researchers who have access, use these salts and in most cases they use very low rates with NPK fertilizers [9]. Currently, it is possible for most small-income farmers who engaged in cultivating vegetables crops such as; okra, pepper and tomato and arable crops like; cassava, yam, coco-yam and maize, to use these soluble micronutrients which are less expensive and available. Field experiments conducted in coastal plain sand derived soils, using $\mathrm{Cu}$ and $\mathrm{Zn}$ on low micronutrients soils to increase the yield of maize production, have shown some crop response, but yield levels of maize obtained to date without them are however, relatively low. Similarly, [10] reported a yield range from 1.76 to $5.84 \mathrm{t} \cdot \mathrm{ha}^{-1}$ from treatment rates of $2.5 \mathrm{~kg}$ $\mathrm{Cu} \cdot \mathrm{ha}^{-1}$ and $5 \mathrm{~kg} \mathrm{Zn} \cdot \mathrm{ha}^{-1}$, however, the soils in southeastern Nigeria environment could support yields in excess of $5 \mathrm{t} \cdot \mathrm{ha}^{-1}$ once the limiting nutrients are corrected [4] [11]. Currently, the status of available Cu and Zn in these soils is not known. Otherwise, the area has a favourable climate and the soils have good physical properties such as good tilt, moderately water-holding capacity, and good aeration [11] [12]. Such conditions are favourable for high yields of maize once any limiting nutrients are corrected [11]. It is hoped that the application of Cu and $\mathrm{Zn}$ will increase and sustain maize production; improve their content in the maize plant and grain which is essential for human and animal growth and development.

Current and past researches in other Nigerian soils and specifically savanna area of northern Nigeria, demonstrate that the application of $\mathrm{Cu}$ and $\mathrm{Zn}$ to maize crop has led to a significant increase in maize [3] [13] [14] and relative yields was closely correlated with extractable $\mathrm{Cu}$ and $\mathrm{Zn} \mathrm{[11]} \mathrm{[15].} \mathrm{Although,} \mathrm{the} \mathrm{researches} \mathrm{carried} \mathrm{out}$ in the savanna area of northern Nigeria showed responses of maize to $\mathrm{Cu}$ and $\mathrm{Zn}$ fertilization, but could also be studied in acid sands of southeastern Nigeria, with different soil characteristics and ecological zone, which need further improvement.

Keeping in view the importance of maize crop and nutritional role of $\mathrm{Cu}$ and $\mathrm{Zn}$ in increasing maize yield in coastal plain sands of southeastern Nigeria soils, greenhouse and field experiments were conducted with the main objectives to determine the status of copper and zinc in acid sands of Calabar soils, response of maize to $\mathrm{Cu}$ and $\mathrm{Zn}$ application and to determine the appropriate application levels of the two nutrient elements for increase and sustainable grain yields, yield components by maize under the prevailing conditions of coastal plain sands derived soils of southeastern Nigeria.

\section{Materials and Methods}

Soil samples were collected from a site that had not been treated with micronutrient fertilizers for the past 12 years for laboratory and greenhouse experiments. The site which has a high potential for dual seasons maize production was selected to represent coastal plain sand derived soil of southeastern, Nigeria [16]. The soil is also suitable for production of upland/swamp rice, okra, yam, citrus, oil palms, plantain/banana and recently some pineapple genotypes (GV. III), and some new cassava varieties from National Root Crop Research Institute, 
Umudike, Abia State Nigeria, have been introduced into the area because of their high market demands for local consumption and export.

\subsection{Laboratory Study}

Laboratory study was conducted to determine some physical and chemical properties and status of total and available $\mathrm{Cu}$ and $\mathrm{Zn}$ in the study area having been informed that these nutrients to be limiting micronutrients [3]. Before the study, eight core surface soil samples $(0-20 \mathrm{~cm})$ were taken each from the two experimental plots and these were bulked together to form two composite samples. The samples were analyzed for $\mathrm{pH}\left(\mathrm{H}_{2} \mathrm{O}\right)$ as described by Thomas [17], organic carbon was determined by wet oxidation [18], available $\mathrm{P}$ was determined by Bray I method [19], and total $\mathrm{N}$ was determined by Kjeldahl procedure of Bremner [20]. Effective cation exchange capacity and exchangeable cations were determined by the method described as in [21]. Micronutrients$\mathrm{Cu}$ and $\mathrm{Zn}$ were extracted with $0.1 \mathrm{~N} \mathrm{HCl}$ as described as in [8] and the concentration of nutrients determined with atomic adsorption spectrophotosmeter (Unicam Solaar 32: Cu Astm D1688; Zn Astm D1691).

\subsection{Greenhouse Study}

The greenhouse experiments were conducted to determine the optimum rate of $\mathrm{Cu}$ and $\mathrm{Zn}$ to maize dry matter yield and uptake, having observed in the laboratory experimental results that, these nutrients to be most deficient micronutrients. One kilogram of the soils was weighed into plastic pots of $2 \mathrm{~L}$ capacity placed on flat plastic receiver. The plastic pots were arranged in a complete randomized design (CRD) with four replications. The number of treatments for each experiment was seven while, the total number of plastic pots was $28(7 \times 4)$. Rates of $120 \mathrm{~kg} \cdot \mathrm{N} \cdot \mathrm{ha}{ }^{-1}, 60 \mathrm{~kg} \cdot \mathrm{P} \cdot \mathrm{ha}^{-1}, 60 \mathrm{~kg} \cdot \mathrm{K} \cdot \mathrm{ha}^{-1}$, and different levels of $\mathrm{Cu}$ and $\mathrm{Zn}(0,2,4,6,8,10$ and 12 $\mathrm{kg} \cdot \mathrm{ha}^{-1}$ ) as $\mathrm{CuSO}_{4}$ and $\mathrm{ZnSO}_{4}$ were used. Six seeds of Oba Supper II maize cultivar were sown per pot and thinned to four, two weeks following emergence. The reason for the small amount of soil and the number of maize seeds planted per pot was for research purpose, the soils need to be stressed up so that the levels of micronutrient applied will be able to establish a response curve. The soils in the pots were maintained at field capacity during the greenhouse study period by watering with deionized water. Plant shoots were harvested at 42 days after planting (6 WAP) by uprooting the entire maize plant (shoots and roots) from the soil. Maize plants were oven dried at $65^{\circ} \mathrm{C}$ to constant weight. The dried plant samples were cut into small pieces and ground to pass through a $0.5 \mathrm{~mm}$ sieve for tissue analysis. The plant sample was digested with tri-acid using $\mathrm{H}_{2} \mathrm{SO}_{4}-\mathrm{NHO}_{3}-\mathrm{HCLO}_{4}$ [22] in Teflon crucible, heated on a hot plate. The content of $\mathrm{Cu}$ and $\mathrm{Zn}$ in the extracts were analyzed by atomic absorption spectrophotometer (Unicam model 939 AAS). Nutrient uptake (mg. plant ${ }^{-1}$ ) of maize plant was determined by multiplying dry matter yield (g. plant ${ }^{-1} \mathrm{MD}$ ) and concentrations of $\mathrm{Cu}$ and $\mathrm{Zn}\left(\mathrm{mg} \cdot \mathrm{kg}^{-1}\right.$ ) in plants [23].

\subsection{Field Experiments}

\subsubsection{Location of the Study Site}

The study site is at Calabar in Cross River State, located within Latitude $4^{\circ} \mathrm{N}^{\prime}$ and $7^{\circ} \mathrm{N}^{\prime}$, and Longitude $8^{\circ} \mathrm{E}^{\prime}$ and $8.30^{\circ} \mathrm{E}$ ' and in southern part of the tropical rain forest zone of Nigeria, to study the effects of various levels of $\mathrm{Zn}$ on grain yield, yield component and uptake by maize (Zea mays L.) at one of the sites where soil samples had been used for the greenhouse study (Table 1). The field was fairly flat and had been under continuous and intensive cultivation without the micronutrients fertilization. The soil is classified as Typic Paleudult according to USDA [24]. The parent materials (coastal plain sands) of the area consist of tertiary coastal sand deposits identified as quaternary [25]. These soils ranged from coarse to fine sandy texture [26]. According to FDALR [26], the parent materials greatly influences the type of soil found within the experimental site. The site experiences the south-westerly and northeasterly winds which is associated with the warm humid Maritime Tropical (MT) air mass respectively. As a result of the movement of these air masses winds, the region is characterized by two seasons-the wet season and the dry season. The wet season starts about March and last till October. This region has 2 - 3 months of dry seasons during which the total rainfall is less than $60 \mathrm{~mm}$. The annual rainfall of the area was recorded as $3063 \mathrm{~mm}$ [27].

\subsubsection{Experimental Design, Field Plan, and Treatments}

Two separate experiments were conducted for $\mathrm{Cu}$ and $\mathrm{Zn}$, using a randomized complete block design (RCBD), 
Table 1. Mean annual and monthly precipitation (P), potential evapotranspiration (PET) and water balance for the location in Cross River State.

\begin{tabular}{ccccccccccccccc}
\hline Station & Parameter & Jan. & Feb. & Mar. & April & May & June & July & Aug. & Sept. & Oct. & Nov. & Dec. & Year \\
\hline \multirow{3}{*}{ Calabar } & P & 40 & 71 & 161 & 222 & 306 & 419 & 449 & 411 & 421 & 325 & 188 & 50 & 3063 \\
& PET & 80 & 85 & 91 & 85 & 79 & 64 & 53 & 51 & 58 & 69 & 76 & 83 & 887 \\
& P-PET & -40 & -14 & 70 & 137 & 227 & 355 & 396 & 360 & 363 & 256 & 112 & -33 & 2176
\end{tabular}

Source: NIMETS [27].

with 7 treatments, replicated four times to give $(7 \times 4) 28$ experimental plots. The dimension of each experimental plot was $6 \mathrm{~m} \times 10 \mathrm{~m}\left(60 \mathrm{~m}^{2}\right)$, with interblock and interplot spacing of 2.5 and $2.0 \mathrm{~m}$, respectively. A 2-m wide pathway was maintained around the entire experimental area. Maize seeds were sown at the spacing of 75 by $25 \mathrm{~cm}$. Three seeds of Oba Supper 11 maize cultivar were sown manually and 14 days after sowing, thinning to two seedlings was performed (recommended seed rate for this cultivar of maize in the rainforest zone for sole cropping at a plant population of 106,666 plant $\cdot \mathrm{ha}^{-1}$ ). Recommended doses of N, P and K at 120, 90 and 60 $\mathrm{Kg} \cdot \mathrm{ha}^{-1}$, respectively were applied uniformly as Urea, SSP, MOP to all the plots three weeks after planting as a basal NPK fertilizers application [4]. $\mathrm{Cu}$ and $\mathrm{Zn}$ were applied at rates of $(0.0,2.0,4.0,6.0,8.0,10.0$ and 12.0 $\mathrm{Kg} \cdot \mathrm{ha}^{-1}$ ) as $\mathrm{CuSO}_{4}$ and $\mathrm{ZnSO}_{4}$, respectively, as side dressing. The reason for the selection of such high range rates of $\mathrm{Cu}$ and $\mathrm{Zn}$ was to observe the response curve for academic research purposes. Moreover, similar higher rates for $\mathrm{Zn}$ have also been reported in an earlier study conducted by Rashid and Fox [28]. Plants were sampled at 9 weeks after planting by taking three ear leaves per row from each of the net six out of eight rows, giving a total of 18 leaves per plot [10], when about $50 \%$ of maize plants had tasseled. The samples were oven dried at $65^{\circ} \mathrm{C}$ to constant weight, cut into small pieces, and ground to pass through a $0.5 \mathrm{~mm}$ sieve for chemical analysis. Plants were grown till maturity, after which cobs were harvested at 120 days after which cobs were shelled; grain yields were measured and converted into tones $\cdot \mathrm{ha}^{-1}$ at $12.5 \%$ moisture. Grains were ground using a Willey mill and digested using a tri-acid mixture of $\mathrm{H}_{2} \mathrm{SO}_{4}: \mathrm{HNO}_{3}: \mathrm{HClO}_{4}(1: 2: 1)$ as described before, and analyzed for $\mathrm{Cu}$ and $\mathrm{Zn}$ using atomic absorption spectrophotometer.

\subsection{Statistical Analysis}

The data collected were subjected to analysis of variance (ANOVA) procedure, using general linear model as in [29] and PASW Statistics 18 for Window 7.0. Significant means were separated using Fisher's Least Significant Different were appropriate at $\mathrm{P}<0.05$. Also correlation and regression analysis was carried out to establish the relationship between soil available $\mathrm{Cu}$ and $\mathrm{Zn}$ content, soil properties and yield parameters.

\section{Results and Discussion}

\subsection{Laboratory Study}

\subsubsection{Soil Properties of the Study Site}

Some physical and chemical properties of the experimental soils derived from coastal plain sand are shown in Table 2. The $\mathrm{pH}$ of the soil is 4.67 and is rate as low [11]. The optimum soil $\mathrm{pH}$ range for maize production is between 5 and 7 [3]. The $\mathrm{pH}$ of 4.67 could be considered suitable for crop production when other soil and plant factors are not limiting. Organic carbon in soil was found to be $1.06 \%$. This value is rated to be low [30]. The low organic carbon could be explained by the fact that coastal plain sand derived soils normally have low organic carbon content [12] [25]. Nitrogen content in the soil was $0.19 \mathrm{~g} \cdot \mathrm{kg}^{-1}$. Landon [30] categorized soil total $\mathrm{N}$ to range from 0.14 to $2.0 \mathrm{~g} \cdot \mathrm{kg}^{-1}$ as low, but soil total $\mathrm{N}$ ranged from $0.15 \%-0.20 \%$ and was rated as moderately low [31]. Therefore, total $\mathrm{N}$ in the soil is rated as low. The Bray 1 (available) $\mathrm{P}$ content of the soil was $12.23 \mathrm{mg} \cdot \mathrm{kg}^{-1}$. Eextractable P (Bray 1 method) was categorized in soils as follows: high ( $\left.>50\right)$; medium (15 - 50) and low $(<15)$ [25] [30]. Therefore, an available $\mathrm{P}$ of $12.23 \mathrm{mg} \cdot \mathrm{kg}^{-1}$ by the bray $\mathrm{l}$ method is very low, implying that the soil is deficient in $\mathrm{P}$.

\subsubsection{Status of Available Copper and Zinc in the Soil before the Experiment}

The $\mathrm{HCl}$-extractable $\mathrm{Cu}$ in the soil was $0.46 \mathrm{mg} \cdot \mathrm{kg}^{-1}$. Levels of 0.5 to $1.0 \mathrm{mg} \cdot \mathrm{kg}^{-1}$ was being suggested to be the 
Table 2. Some soil physical and chemical properties of experimental site.

\begin{tabular}{|c|c|c|c|c|}
\hline $\mathrm{S} / \mathrm{NO}$ & Soil parameter & Unit & Value & Rating \\
\hline 1 & $\mathrm{pH}$ in water & & 4.79 & Low \\
\hline 2 & Organic Carbon & $\%$ & 1.06 & low \\
\hline 3 & Available P (Bray 1) & $\mathrm{mg} \cdot \mathrm{kg}^{-1}$ & 12.23 & Low \\
\hline 4 & Total N & $\%$ & 0.19 & low \\
\hline 4 & Cation exchange capacity & $\mathrm{cmol} \cdot \mathrm{kg}^{-1}$ & 16.89 & Low \\
\hline 5 & Exchangeable Ca & $\mathrm{cmol} \cdot \mathrm{kg}^{-1}$ & 3.60 & Medium \\
\hline 6 & Exchangeable Mg & $\mathrm{cmol} \cdot \mathrm{kg}^{-1}$ & 2.04 & Medium \\
\hline 7 & Exchangeable $\mathrm{K}$ & $\mathrm{cmol} \cdot \mathrm{kg}^{-1}$ & 1.34 & High \\
\hline 8 & Exchangeable Na & $\mathrm{cmol} \cdot \mathrm{kg}^{-1}$ & 0.15 & Low \\
\hline 9 & Exchangeable acidity & $\mathrm{cmol} \cdot \mathrm{kg}^{-1}$ & 1.30 & - \\
\hline 10 & $\mathrm{HCl}$-extractable $\mathrm{Cu}$ & $\mathrm{mg} \cdot \mathrm{kg}^{-1}$ & 0.26 & Low \\
\hline \multirow[t]{2}{*}{11} & HCl-extractable Zn & $\mathrm{mg} \cdot \mathrm{kg}^{-1}$ & 0.19 & Low \\
\hline & Particle size analysis & & & \\
\hline 12 & Sand & $\%$ & 75.60 & \\
\hline 13 & Silt & $\%$ & 9.10 & \\
\hline 14 & Clay & $\%$ & 15.30 & \\
\hline 15 & Textural class & & Loamy sand & \\
\hline
\end{tabular}

critical levels for $\mathrm{Cu}$, therefore, the concentration of $0.46 \mathrm{mg} \mathrm{Cu} \cdot \mathrm{kg}^{-1}$ in the soil is rated as low, and this was contributed be due to low $\mathrm{pH}$ and organic matter of the soil [9]. Similarly, the $\mathrm{HCl}$ extractable $\mathrm{Zn}$ was found to be $0.19 \mathrm{mg} \cdot \mathrm{kg}^{-1}$. Accordingly, [9] [11] [32], reported that the critical level of HCl-extractable $\mathrm{Zn}$ in the soil ranged from 0.2 to $1.0 \mathrm{mg} \cdot \mathrm{kg}^{-1}$; therefore, an HCl-extractable $\mathrm{Zn}$ level of $0.19 \mathrm{mg} \cdot \mathrm{kg}^{-1}$ in the soil is low or marginal, since it is below the soil critical levels reported. This finding is also in agreement with the report presented by [33] elsewhere in savanna soils of Northern Nigeria. The low available $\mathrm{Cu}$ and $\mathrm{Zn}$ in the soil as presented in Table 2, may be attributed to their low content in the parent material [34], low soil organic matter [35] and sorption or redox potential due to the prevailing $\mathrm{pH}$ of the soil [36] [37].

\subsection{Greenhouse Experiments}

\subsubsection{Response of Maize to Cu and Zinc}

Dry Matter Production of Maize Plants

An impressive effect of $\mathrm{Cu}$ treatment, on DM yields was determined. The DM yields of maize shoots differ significantly $(\mathrm{P}<0.05)$ among the levels of $\mathrm{Cu}$ treatments, and this significantly increased $\mathrm{DM}$ yields from 6.82 to $17.69 \mathrm{~g}$. plant ${ }^{-1}$ (Table 3). Higher dry matter yield was obtained at $10 \mathrm{~kg} \cdot \mathrm{Cu} \cdot \mathrm{ha}^{-1}$ over control as given in Table 3. The significant $(\mathrm{P}<0.05)$ increase in $\mathrm{DM}$ yield in the $\mathrm{Cu}$ treatments over the control suggests that $\mathrm{Cu}$ was one of the limiting nutrients in the soils (Table 3). However, the rate of $10 \mathrm{~kg} \cdot \mathrm{Zn} \cdot \mathrm{ha}^{-1}$ will be required for optimizing maize yields in the soils, showing that this treatment improved better $\mathrm{Cu}$ nutrition for maize dry matter production in the soil, which in turn will improve maize grain yields.

Similarly, Zn levels significantly increased DM yields from 5.60 to $19.63 \mathrm{~g} \cdot$ plant $^{-1}$. The high increase in DM yields as a result of $\mathrm{Zn}$ application to the soil suggests that $\mathrm{Zn}$ was a limiting nutrient in the soil under review. The treatment that received $8 \mathrm{~kg} \cdot \mathrm{Zn} \cdot \mathrm{ha}^{-1}$ gave significantly higher DM yield over control treatment. This indicates that, at this level, the soil $\mathrm{Zn}$ was further improved with better $\mathrm{Zn}$ nutrition leading to high DM production. Further addition of Zn to the soil after $8 \mathrm{~kg} \cdot \mathrm{Zn} \cdot \mathrm{ha}^{-1}$ level, did not significantly in improve DM yield of plant shoots. This finding is in agreement with result reported in [10]. This which suggests that in this study, 8 $\mathrm{kg} \cdot \mathrm{Zn} \cdot \mathrm{ha}^{-1}$ is the critical nutrient level that will optimize maize yields in Calabar acid sands soils. 
Table 3. Effect of $\mathrm{Cu}$ and $\mathrm{Zn}$ levels on dry matter yield and their nutrient content in maize plant shoots.

\begin{tabular}{|c|c|c|}
\hline Treatments & Dry matter yield $\left(\mathrm{g} \cdot\right.$ plant $\left.^{-1}\right)$ & Nutrients content in maize plant shoots ( $\mathrm{mg} \cdot \mathrm{kg}^{-1}$ ) \\
\hline \multicolumn{3}{|c|}{ Cu levels $\left(\mathrm{kg} \cdot \mathrm{ha}^{-1}\right)$} \\
\hline 0 & 6.82 & 4.69 \\
\hline 2 & 10.66 & 6.28 \\
\hline 4 & 13.93 & 6.53 \\
\hline 6 & 14.26 & 7.08 \\
\hline 8 & 16.01 & 7.12 \\
\hline 10 & 17.69 & 7.80 \\
\hline 12 & 15.52 & 7.21 \\
\hline $\mathrm{LSD}_{0.05}$ & 1.86 & 1.03 \\
\hline $\mathrm{CV} \%$ & 10.07 & 9.80 \\
\hline \multicolumn{3}{|c|}{ Zn levels $\left(\mathrm{kg} \cdot \mathrm{ha}^{-1}\right)$} \\
\hline 0 & 5.60 & 3.15 \\
\hline 2 & 9.45 & 4.58 \\
\hline 4 & 15.86 & 7.78 \\
\hline 6 & 17.71 & 9.97 \\
\hline 8 & 19.63 & 10.40 \\
\hline 10 & 18.22 & 8.71 \\
\hline 12 & 16.79 & 8.15 \\
\hline $\mathrm{LSD}_{0.05}$ & 3.28 & 1.25 \\
\hline CV \% & 12.8 & 32.2 \\
\hline
\end{tabular}

\subsubsection{Concentration of Copper and Zinc Maize Shoots}

The amounts of $\mathrm{Cu}$ concentrations in maize shoots are shown in Table 3. Copper concentration ranged from 4.63 to $9.47 \mathrm{mg} \cdot \mathrm{kg}^{-1}$, these were far above the critical ranges of 0.2 to $1.0 \mathrm{mg} \cdot \mathrm{kg}^{-1} ; 1.2$ to $4.5 \mathrm{mg} \cdot \mathrm{kg}^{-1}$ and a critical value of $5 \mathrm{mg} \cdot \mathrm{kg}^{-1}$ reported by in [10] [38] [39], respectively. Moreover, Cu application increased Cu uptake significantly compared with the control, signifying that $\mathrm{Cu}$ was one of the limiting nutrients in this soil (Table 3). Surprisingly, lower levels of Cu also yielded higher concentration in maize shoots. It is noted in Table 3 that, $10 \mathrm{~kg} \cdot \mathrm{Cu} \cdot \mathrm{ha}^{-1}$ level applied, which gave the maximum dry matter production also gave significantly $(\mathrm{P}<$ 0.05) higher $\mathrm{Cu}$ content relative to lower levels of $\mathrm{Cu}$. However, this rate of $\mathrm{Cu}$ is relatively high, suggesting that this soil has low Cu fixation [8].

Similarly, zinc concentrations in maize shoots varied between 3.15 and $10.40 \mathrm{mg} \cdot \mathrm{kg}^{-1}$ (Table 3) and these were below the range of 10.8 to $18.9 \mathrm{mg} \cdot \mathrm{kg}^{-1}$ obtained in [10] and critical levels of 25 to $60 \mathrm{mg} \cdot \mathrm{kg}^{-1}$ established as in [40], however, these were above the critical level $7 \mathrm{mg} \cdot \mathrm{kg}^{-1}$ for maize at 42 days of age [39]. Table 3 above showed that $8 \mathrm{~kg} \cdot \mathrm{Zn} \cdot \mathrm{ha}^{-1}$ level generated significantly $(\mathrm{P}<0.05)$ higher $\mathrm{Zn}$ content in maize shoot over control. Interestingly, at this levels the application of Zn significantly $(\mathrm{P}<0.05)$ gave higher DM yields relative to lower treatments and those above it, suggesting that, there is a dilution of $\mathrm{Zn}$ in the maize plant by the rapid maize growth and yield, as found in dry matter production, Zn concentration and $\mathrm{Zn}$ uptake in plant shoots (Table 3 and Figure 2), respectively.

\subsubsection{Estimation of Optimum Copper and Zinc Levels for Maize Production in Calabar Acid Sands Soil}

1) Uptake of Copper and Zinc

Copper application increased $\mathrm{Cu}$ uptake in maize shoots significantly $(\mathrm{P}<0.05)$, compared with the control, indicating that $\mathrm{Cu}$ must have been one of the limiting nutrients in the soil and it was also in this treatment level 
where significantly, higher Dm yield was obtained. The treatment that received $10 \mathrm{~kg} \cdot \mathrm{Cu} \cdot \mathrm{ha}^{-1}$ gave significant higher uptake than treatments with low $\mathrm{Cu}$ levels as indicated in Figure 1, suggesting that this level improved $\mathrm{Cu}$ supply further, thereby leading to better $\mathrm{Cu}$ nutrition. Figure 1 also indicated that Calabar acid sands soils contain a low to marginal level of $\mathrm{Cu}$ that is why there was this impressive response of maize to $\mathrm{Cu}$ application. However, further addition of $\mathrm{Cu}$ in the soil above the $10 \mathrm{~kg} \cdot \mathrm{Cu} \cdot \mathrm{ha}^{-1}$, did not yield any increase in Cu uptake significantly, probably due to a dilution affect as a result of the increased in DM yield in maize shoot. Accordingly, the polynomial regression analysis $\left(\mathrm{Y}=0.3238+0.1791 \mathrm{X}-0.009 \mathrm{X}^{2} ; \mathrm{R}^{2}=0.9496\right)$ computed for $\mathrm{Cu}$ uptake as shown in Figure 1, suggest that the optimum levels for $\mathrm{Cu}$ uptake in maize shoots as influenced by $\mathrm{Cu}$ levels to be $10.06 \mathrm{~kg} \cdot \mathrm{Cu} \cdot \mathrm{ha}^{-1}$.

Similarly, there was a significant effect of different levels of $\mathrm{Zn}$ application on $\mathrm{Zn}$ uptake in maize plants (Figure 2). The incremental addition of $\mathrm{ZnSO}_{4}$ to the soil significantly $(\mathrm{P}<0.05)$ improved $\mathrm{Zn}$ uptake in maize, leading to the maximum increase in $\mathrm{Zn}$ uptake of maize shoots and this was determined in $\mathrm{Zn}$ applied at 8 $\mathrm{kg} \cdot \mathrm{Zn} \cdot \mathrm{ha}^{-1}$ over the control treatment (Figure 2). This result may be due to the increase in either DM yield or Zn concentration which accumulated Zn content in the various plant parts. This finding is in agreement with those reported as in [41]-[43]. Elsewhere as in [10], higher rates than the rate used in this study were applied, and obtained a similar result. It is however, noted in Figure 2 that, Zn uptake was significantly $(P<0.05)$ increased according to levels of $\mathrm{Zn}$ fertilizer applied, while at $12 \mathrm{~kg} \cdot \mathrm{Zn} \cdot \mathrm{ha}^{-1}, \mathrm{Zn}$ uptake by maize descended. Furthermore, the polynomial regression analysis computed for $\mathrm{Zn}$ uptake $\left(\mathrm{Y}=0.0048+0.4377 \mathrm{X}-0.0266 \mathrm{X}^{2} ; \mathrm{R}^{2}=\right.$ 0.931 ) indicated that the optimum level for $\mathrm{Zn}$ uptake in maize shoots as influenced by levels of $\mathrm{Zn}$ is also determined to be $8 \mathrm{~kg} \cdot \mathrm{Zn} \cdot \mathrm{ha}^{-1}$ in Calabar acid sands soils. The result of this study indicates that the soils of

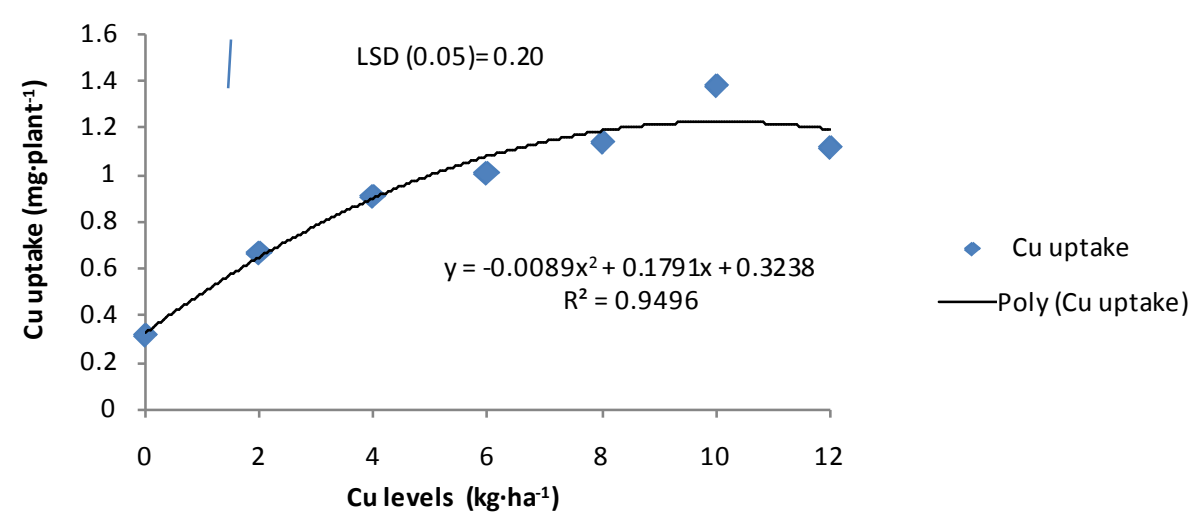

Figure 1. Optimum levels of $\mathrm{Cu}$ uptake on maize plant in greenhouse study. Vertical bar represents LSD at 0.05 .

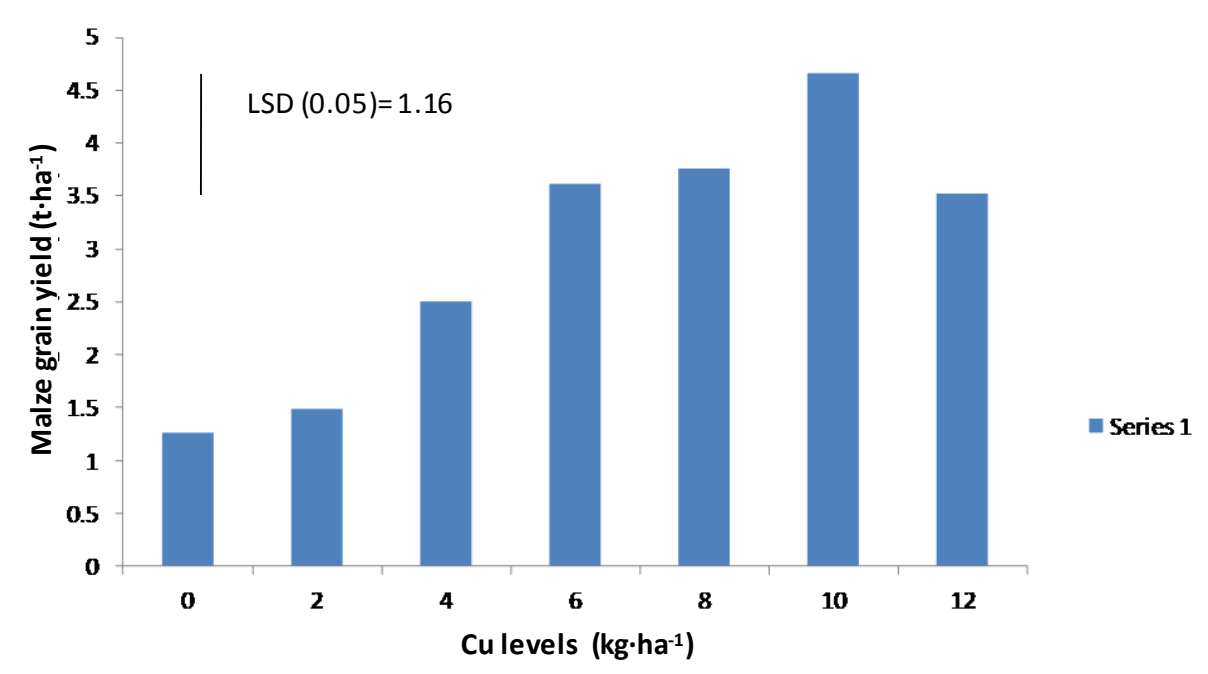

Figure 2. Effect of $\mathrm{Cu}$ levels on maize grain yields. Vertical bar represents LSD (0.05). 
Calabar, Nigeria exhibited a highly variable capacity to accumulate Zn due to Zn supplement, less fixation and greater transport of the nutrient to plant roots [4] [31].

\subsection{Field Experiments}

\section{Maize Grain Yields}

Result on Figure 3 showed that maximum grain yield was obtained with the application of $10 \mathrm{~kg} \cdot \mathrm{Cu} \cdot \mathrm{ha}^{-1}$ and minimum was recorded in the control plot. It is also evident from Figure 3 that all the copper treated plots significantly $(\mathrm{P}<0.05)$ increased the grain yield over the control, as there was a consistent increase in maize grain yield up to $10 \mathrm{~kg} \cdot \mathrm{Cu} \cdot \mathrm{ha}^{-1}$, perhaps due to toxic level of applied $\mathrm{Cu}$. This suggest that, the application of Cu significantly $(\mathrm{P}<0.05)$ influenced the increased in maize grain yield. Similar results were reported as in [10]. The result is in accord with the earlier report that plants grown in acid sands respond to $\mathrm{Cu}$ application even if the soil is not deficient in available $\mathrm{Cu}$ [44]. However, the low grain yield obtained in control plots suggest that the soils was actually deficient in $\mathrm{Cu}$ available to the plants, being that this level is critical for growing maize. Generally, the grain yield enhancement at $10 \mathrm{~kg} \cdot \mathrm{Cu} \cdot \mathrm{ha}^{-1}$ suggest that, this is the level required for optimum maize production in the soils under review.

Similarly, the application of Zn significantly $(\mathrm{P}<0.05)$ increased maize grain yields (Figure 4). Maize grain yield was significantly increased by the application of $8 \mathrm{~kg} \cdot \mathrm{Zn} \cdot \mathrm{ha}^{-1}$, however, further addition did not significantly result in corresponding yield increase (Figure 4). This may be due to $\mathrm{Zn}$ levels in the soils. This rate was lower than the level obtained as reported in [45] who reported a grain yield increase of 116.25 as a result of 10 $\mathrm{kg} \cdot \mathrm{Zn} \cdot \mathrm{ha}^{-1}$ application over control, elsewhere in Ghana. However, the level obtained in this study was higher than the optimum level obtained in [43] who reported a grain yield increased in maize from 1977-1999 ranged

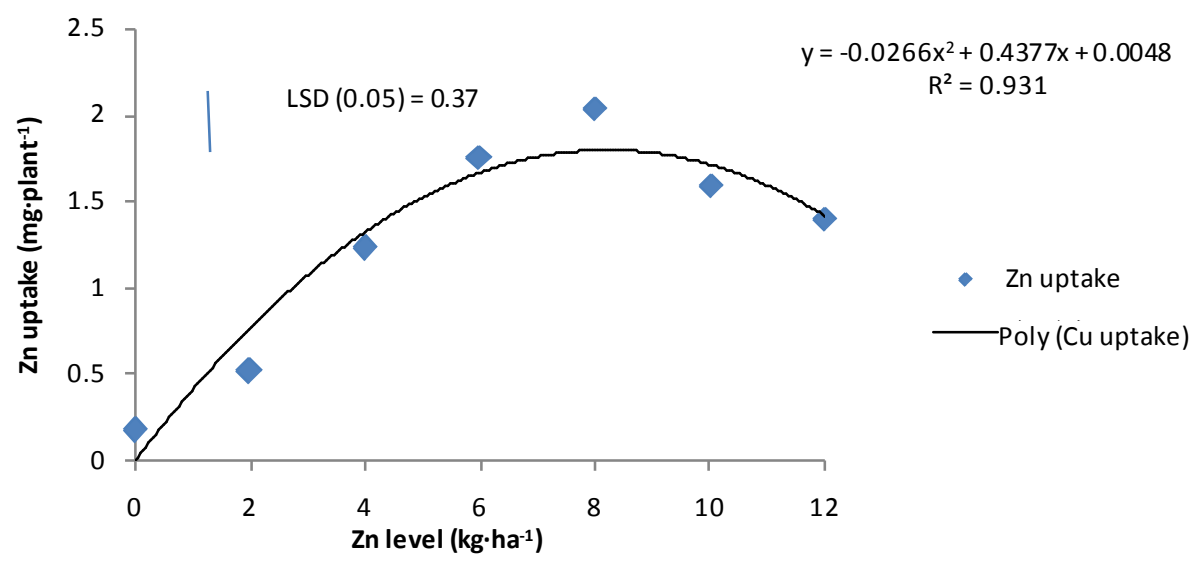

Figure 3. Optimum levels of Zn uptake on maize plants in greenhouse study. Vertical bar represent $L S D$ at 0.05 .

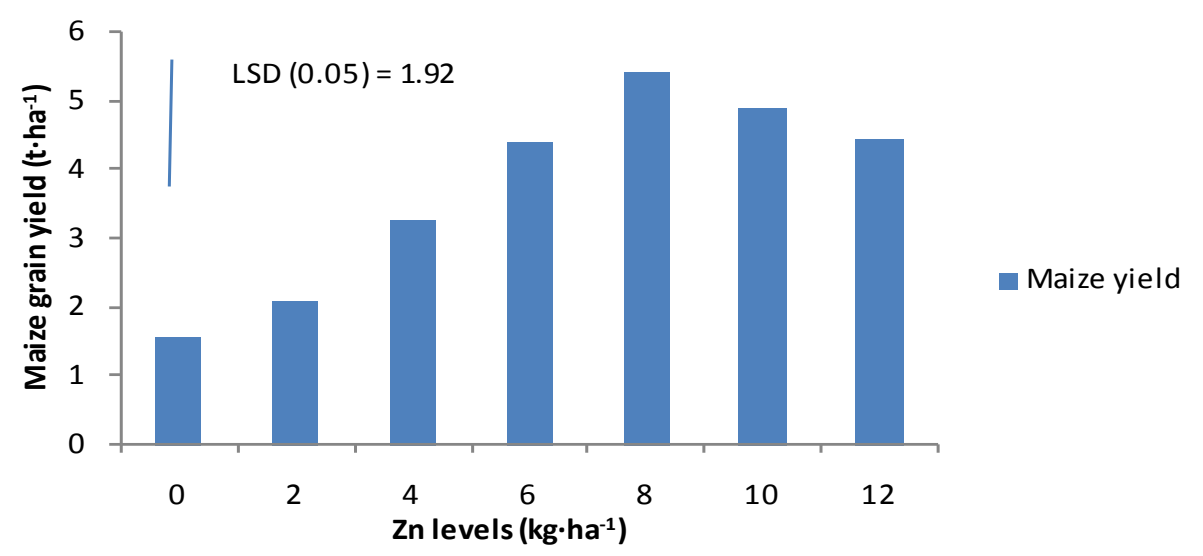

Figure 4. Effect of Zn levels on maize grain yield. 
between $84 \%$ to $108 \%$ with the highest percentage increased at $10 \mathrm{~kg} \cdot \mathrm{Zn} \cdot \mathrm{ha}^{-1}$. Moreover, considering the low levels of $\mathrm{Zn}$ uptake by maize plant and the higher grain yield obtained when $\mathrm{Zn}$ was applied at $8 \mathrm{~kg} \cdot \mathrm{Zn} \cdot \mathrm{ha}^{-1}$, it is an impression that $\mathrm{ZnSO}_{4}$ application at this level is appropriate for maize production in these soils.

However, the application of $\mathrm{Cu}$ and $\mathrm{Zn}$ fertilizers to the maize crop in different experiments, not only enhances its production in the soils, but also increases tissue content and this can cure the micronutrients deficiency problem in human nutrition [46]. Moreover, the response of maize as influenced by levels of $\mathrm{Cu}$ and $\mathrm{Zn}$ fertilizers respectively in separate field experiments are in agreement with those obtained from greenhouse experiments.

\section{Conclusion}

The study clearly demonstrated that coastal plain sand derived soil has severe $\mathrm{Cu}$ and $\mathrm{Zn}$ deficiency. The potential impacts of $\mathrm{Cu}$ and $\mathrm{Zn}$ fertilizers to improve on maize grain yields were clearly demonstrated, appreciably in the soil. A greenhouse experiment estimated approximately a level of $10 \mathrm{~kg} \cdot \mathrm{Cu} \cdot \mathrm{ha}^{-1}$ and $8 \mathrm{~kg} \cdot \mathrm{Zn} \cdot \mathrm{ha}^{-1}$ to be optimum levels for dry matter production, contents of $\mathrm{Cu}$ and $\mathrm{Zn}$ and its uptake in maize shoots, respectively in the study area. Besides, the application of $\mathrm{Cu}$ and $\mathrm{Zn}$ fertilizers in the field yielded maximum grain yield at the rate of $10 \mathrm{~kg} \cdot \mathrm{Cu} \cdot \mathrm{ha}^{-1}$ and $8 \mathrm{~kg} \cdot \mathrm{Zn} \cdot \mathrm{ha}^{-1}$, respectively. Accordingly, the rates of $10 \mathrm{~kg} \cdot \mathrm{Cu} \cdot \mathrm{ha}^{-1}$ and $8 \mathrm{~kg} \cdot \mathrm{Zn} \cdot \mathrm{ha}^{-1}$ are recommended in Calabar soil to ensure that the yield potentials of maize are achieved. Furthermore, research should be undertaken on the chemistry and adsorption of $\mathrm{Cu}$ and $\mathrm{Zn}$ to identify the adsorption or retention capacity of the soil. Further research should be conducted to evaluate sorption and/or the use of organic $\mathrm{Cu}$ and $\mathrm{Zn}$ fertilizers especially $\mathrm{Cu} / \mathrm{Zn}$-EDTA, Cu/Zn-Lignosulphate and $\mathrm{Cu} / \mathrm{Zn}$-Suc. Also the potentials of these nutrient minerals with other crops like roots and tubers, and vegetable crops in other areas of coastal plain sand derived soil should be examined.

\section{References}

[1] IITA (2010) Annual Report on Maize Production. International Institute of Tropical Agriculture, Ibadan.

[2] FAO (2010) FAO Production Year Book. Food and Agricultural Organization, Rome.

[3] Enwezor, W.O., Ohiri, O.C., Opuwaribu, E.E. and Udo, E.J. (1990) A Review of Fertilizer Use on Crops in Southeastern Zones of Nigeria (in Five Vols.) (FFDD Eds). Boboma Publ., Ibadan, 47-70.

[4] Chude, V.O., Malgwi, W.B., Amapu, I.Y. and Ano, A.O. (2004) Manual on Soil Fertility Assessment. Federal Fertilizer Department/National Special Food Programme for Security, Abuja, 89.

[5] Ogban, P.I., Akwue, I.P. and Mauako, O. (1999) Properties and Management of Catenary Soils on Coastal Plain Sands in Southeastern Nigeria. In: Babalolu, O., Omoti, U. and Isenmila, A.E., Eds., Management of the Soil Resources of Nigeria for Sustainable Agricultural Production in the 21st Century. Proceedings of the 25th Annual Conference of the Soil Science Society of Nigeria, Benin, 45-52.

[6] Onwuka, I.M. (2008) Amelioration of Soil Acidity Using Local Liming Materials and Their Effects on Maize Performance in an Ultisols of Southeastern Nigeria. Ph.D. Thesis, Department of Soil Science and Meteorology, Michael Okpara University of Agriculture, Umudike, 123.

[7] Sillanpaa, M. (1982) Micronutrients and the Nutrient Status of Soils: A Global Study. FAO Soil Bulletin No. 48, FAO/ Finnish International Development agency, Rome.

[8] Osiname, O.A., Schulte, E.E. and Core, R.B. (1973) Soil Tests for Available Copper and Zinc in Soils of Western Nigeria. Journal of the Science of Food and Agriculture, 24, 1341-1349. http://dx.doi.org/10.1002/jsfa.2740241105

[9] Kparmwang, T., Chude, V.O., Raji, B.A. and Odunze, A.C. (2000) Extractable Micronutrients in Some Soils Developed on Sandstone and Shale in Benue Valley, Nigeria. Nigerian Journal of Soil Science Research, 1, 42-48.

[10] Lisuma, J.B., Semoka, J.M.R. and Semu, E. (2006) Maize Yield Response and Nutrient Uptake after Micronutrient Application on a Volcanic Soil. Agronomy Journal, 98, 402-406.

[11] Aduayi, E.A., Chude, V.O., Adebusuyi, B.A. and Olayiwola, S.O. (2002) Fertilizer use and Management Practices for Crops in Nigeria. Federal Fertilizer Distribution Department. Federal Ministry of Agriculture and Rural Development, Abuja, 126.

[12] Enwezor, W.O., Udo, E.J. and Sobulo, R.A. (1981) Fertility Status and Productivity of Acid Sands. In: Acid Sands of Southeastern Nigeria, SSSN Special Publication Lagos, Nigeria, Monograph No. 1: 56-73.

[13] Iwuafor, E.N., Chude, V.O. and Amapu, I. (1991) Response of Maize (Zea mays L.) to Various Rates of Zinc Fertilizer in the Semi-Arid Zone of Nigeria. SAFGRA Network's Joint Workshop, Niamey, 8-14 March 1991. 
[14] Yusuf, A.A., Abdu, N., Chude, V.O., Yusuf, H.A. and Pam, S.G. (2005) Response of Maize (Zea mays L.) to Zinc Fertilization in Relation to Mehlich 1 Extractable Zinc in Northern Nigeria. Nigeria Journal of Soil Research, 6, 32-41.

[15] Chude, V.O., Iwuafor, E.N.O., Amapu, I.Y. and Pam, S.G. and Yusuf, A.A. (2002) Response of Maize to Zn Fertilization in Relation to Mehlich III Extractable Zinc. (in Press)

[16] Ojanuga, A.G. (2006) Agroecological Zones of Nigeria Manual. In: Berding, F. and Chude, V.O., Eds., National Special Programme for Food Security (NSPFS) and FAO, 124.

[17] Thomas, G.W. (1996) Soil pH and Soil Acidity. In: Sparks, D.L., Ed., Methods of Soil Analysis Part 3: Chemical Methods, SSSA Book Series 5, Soil Science Society of America, Madison, Wisconsin, 475-490.

[18] Nelson, D.W. and Sommers, L.E. (1996) Total Carbon, Organic Carbon and Organic Matter. In: Sparks, D.L., Ed., Methods of Soil Analysis Part 3: Chemical Methods, SSSA Book Series 5, Madison, Wisconsin, Soil Science Society of America, 961-1010.

[19] Kuo, S. (1996) Phosphorus. In: Sparks, D.L., Ed., Methods of Soil Analysis Part 3: Chemical Methods, SSSA Book Series 5, Soil Science Society of America, Madison, Wisconsin, 869-920.

[20] Bremner, J.M. (1996) Nitrogen Total. In: Sparks, D.L., Ed., Methods of Soil Analysis Part 3: Chemical Methods, SSSA Book Series 5, Soil Science Society of America, Madison, Wisconsin, 1085-1122.

[21] Sumner, M.E. and Miller, W.P. (1996) Cation Exchange Capacity and Exchange Coefficients. In: Sparks, D.L., Ed., Methods of Soil Analysis Part 3: Chemical Methods, SSSA Book Series 5, Soil Science Society of America, Madison, Wisconsin, 1201-1230.

[22] Shuman, L.M. (1985) Fractionation Method for Soil Micronutrients. Soil Science, 140, 11-22. http://dx.doi.org/10.1097/00010694-198507000-00003

[23] Whitney, D.A. (1988) Micronutrient Soil Test Zinc, Iron, Manganese and Copper. In: Dahuke, W.C., Ed., Recommended Chemical Soil Test Procedures for the North Central Region, North Dakota Agric. Exp. Stn. Bull. 499 Review, 20-22.

[24] USDA (2006) Keys to Soil Taxonomy. 10th Edition, United States Department of Agriculture, NRCS Soil Conservation Service, Washington DC.

[25] Ibanga, I.J. and Udo, E.J. (1996) Soil Survey and Fertility Baseline Data collection of Akwa Ikot Effangha Farm, Akpabuyo LGA, Cross River State Nigeria. National Agricultural Land Development Authority, Abuja.

[26] FDALR (1995) Federal Department of Agriculture and Land Resources. The Reconnaissance Soil Survey of Cross River State, Nigeria. FDALR, Abuja, 43p.

[27] NIMETS (2009) Nigeria Meteorological Services, Calabar Station, Margerate Ekpo International Airport Calabar, Nigeria.

[28] Rashid, A. and Fox, R.C. (1992) Evaluating Internal Zn Requirements of Grain Crop, In: Methods of Soil Analysis. Part 2: Chemical and Microbiological Properties, Agronomia, Soil Science Society of America, Madison, WI. 9: 570-571.

[29] GenStat (2003) GenStat for Windows. Release 7.2. 7th Edition, VSN International Ltd, Oxford.

[30] Landon, J.R. (1991) Booker Tropical Soil Manual. A Handbook for Soil Survey and Agricultural Land Evaluation in the Tropics and sub Tropics. Longman Scientific \& Technical Publ., Harlon.

[31] Enwezor, W.O., Udo, E.J., Usoro, N.J., Ayotade, J.A., Chude, V.O. and Udegbe, C.C. (1989) Fertilizer Use and Management Practices for Crops in Nigeria. Series 2. Federal Ministry of Agriculture, Water Resources and Rural Development, 52-56.

[32] Tandon, H.L.S. (1995) Micronutrients in Soils, Crops and Fertilizer: A Source Book-Cum-Directory. Fertilizer Development and Consultation Organ, New Delhi.

[33] Abdu, N., Yusuf, A.A., Abdulkadir, A., Arunah, U.L., Chude, V.O. and Pam, S.G. (2007) Zinc Soil Calibration Based on $0.1 \mathrm{~N} \mathrm{HCl}$ Extractable Zinc and Cation Exhangeable Capacity from Upland Soils of Northern Nigeria. Journal of Agronomy, 6, 179-182. http://dx.doi.org/10.3923/ja.2007.179.182

[34] Alloway, B.J. (2004) Zinc in Soils and Crop Nutrition. International fertilizer Industry Association and International Zinc Association, Brussels, Belgium and Paris, 135.

[35] Ano, A.O. and Agwu, J.A. (2005) Effect of Animal Manures on Selected Soil Chemical Properties (1); Exhangeable Acidity. Exchangeable Bases and Organic Carbon. Nigeria Journal of Soil Science, 15, 14-19.

[36] Eshiet, E.T. (1992) Physico-Chemical, Morphological and Mineralogical Characteristics of Selected Humid Region Profiles in Southeastern Nigeria. In: Kimble, J.M., Ed., Proceedings of the Eighth International Soil Correlation Meeting (VIII ISCOM): Characterization, Classification and Utilization of Wet Soils, USDA, Soil Conservation Service, National Soil Survey Center, Lincoln, NE, 100-105. 
[37] Akamigbo F.O.R. and Asadu, C.L.A. (1983) Influence of Parent Materials on the Soils of Southeastern Nigeria. East African Agricultural Journal, 48, 81-91.

[38] Udo, E.J. and Fagbami, A.A. (1979) The Profile Distribution of Total and Extractable Zn in Selected Nigerian Soils. Communications in Soil Science and Plant Analysis, 10, 1141-1161. http://dx.doi.org/10.1080/00103627909366968

[39] Jones, J.B. and Eck, H.V. (1973) Plant Analysis as an Aid in Fertilizing Corn and Grain Sorghum. In: Watsh, L.M. and Beaton, J.B., Eds., Soil Testing and Plant Analysis, SSSA, Madison, WF, 349-364.

[40] Tisdale, L.S., Werner, N.L., Beaton, S.D. and Havlin, J.L. (2003) Soil Fertility and Fertilizers. 6th Edition, PrenticeHall, Upper Saddle River, NJ, 634p.

[41] Rhem, G.W., Wiese, R.A. and Herget, G.W. (1980) Response of Corn to Zn Sources and Rate of Zn Band-Applied with Either Orthophosphate or Polyphosphate. Soil Science, 129, 36-44. http://dx.doi.org/10.1097/00010694-198001000-00007

[42] Kanwal, S., Rahmatullah, A.M. Ranjha and R. Ahmad (2010) Zinc Partitioning in Maize Grain after Soil Fertilization with Zinc Sulphate. International Journal of Agriculture and Biology, 12, 299-302.

[43] Maftoun, M. and Karimian, N. (1989) Relative Efficiency of Two Zn Sources for Maize (Zea mays L.) in Two Calcareous Soils from an Arid Area of Iran. Agronomie, 9, 771-775. http://dx.doi.org/10.1051/agro:19890804

[44] Abunyewa, A.A. and Mercer-Quarshie, H. (2004) Response of Maize to Zinc Application in the Semi Arid Zone of West Africa. Asian Journal of Plant Sciences, 3, 1-5. http://dx.doi.org/10.3923/ajps.2004.1.5

[45] Ibanga, I.J., Lekwa, J., Eko, U.C., Udo-Isong, M.N., Ugwu, T.T. and Ahumile, C. (1989) Soil and Land Use Survey of Cross River State. Main Bulk trade Investment, Calabar.

[46] Frey, E., Frolich, W., Hauffe, H.K. and Rudat, H. (1999) The Effect of Mg and Zn Application to Maize in an Alfisol in Northern Ghana. The 12th National Maize and Legumes Workshop, Technical Institution, Kumasi, 24-26. 
Scientific Research Publishing (SCIRP) is one of the largest Open Access journal publishers. It is currently publishing more than 200 open access, online, peer-reviewed journals covering a wide range of academic disciplines. SCIRP serves the worldwide academic communities and contributes to the progress and application of science with its publication.

Other selected journals from SCIRP are listed as below. Submit your manuscript to us via either submit@scirp.org or Online Submission Portal.
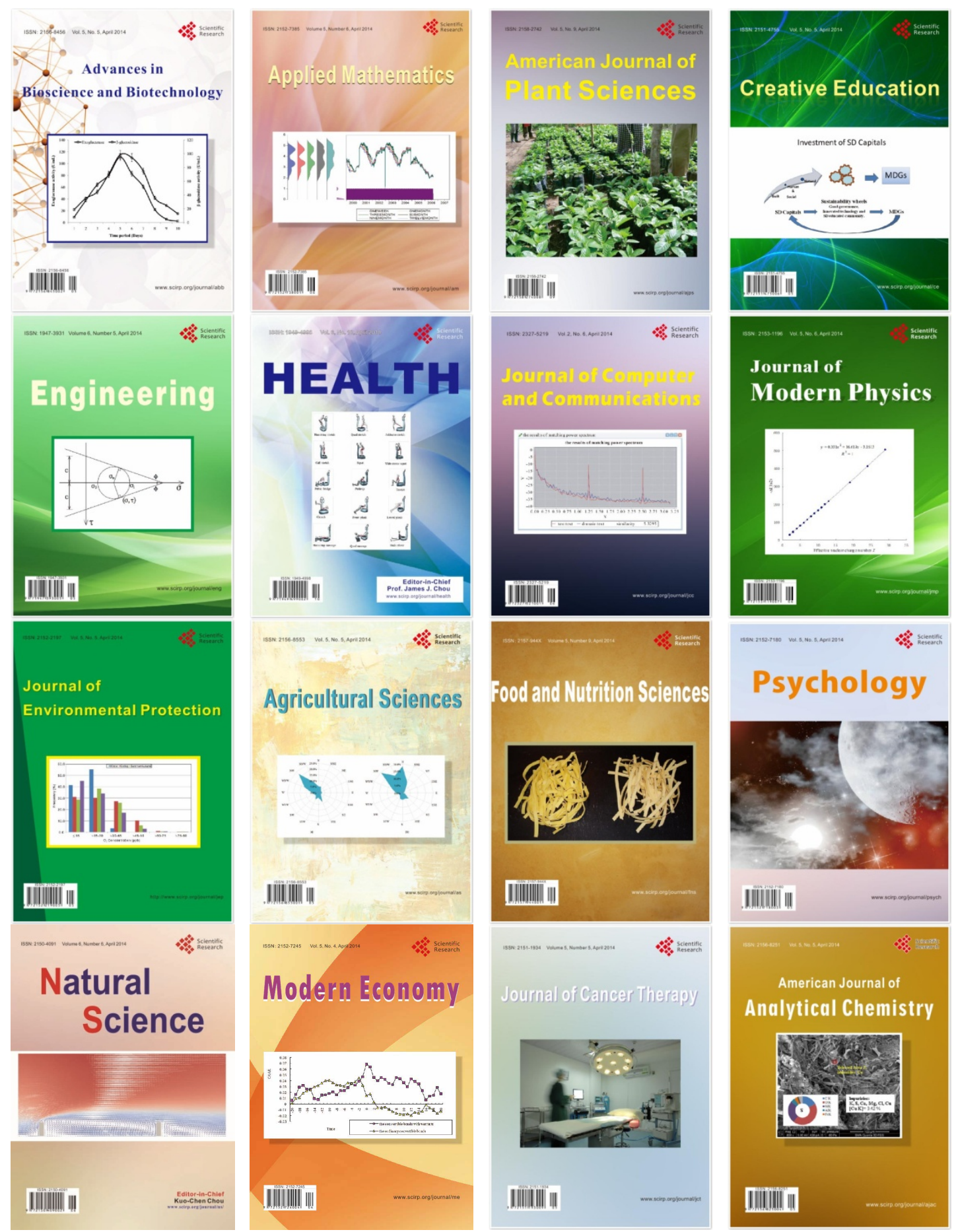